\title{
Chromosomal marker exchange in the thermophilic archaeon Sulfolobus acidocaldarius: physiological and cellular aspects
}

\author{
Farnaz Ghané and Dennis W. Grogan
}

Department of Biological Sciences, University of Cincinnati, PO Box 210006, Cincinnati, OH 45221-0006, USA
Author for correspondence: Dennis W. Grogan. Tel: + 1513556 9748. Fax: + 15135565299. e-mail: Dennis.Grogan@UC.edu

Exchange and recombination of chromosomal markers is an intrinsic genetic property of the thermoacidophilic archaeon Sulfolobus acidocaldarius that has not been thoroughly characterized. To clarify the mechanism and experimental usefulness of this process, the frequency of $S$. acidocaldarius prototrophs produced from mixtures of two pyrimidine auxotrophs under a variety of conditions was determined. The apparent efficiency of genetic exchange was essentially independent of the density of cells deposited on the surface of solid media. Furthermore, recombinant formation could initiate in liquid suspensions, as indicated by high recombinant frequencies resulting from mixtures plated at low cell densities, and the formation of recombinants at equal or higher frequencies in liquid suspensions that were never plated. Apparent initiation of genetic exchange in liquid at $22^{\circ} \mathrm{C}$ was not prevented by DNase, prior digestion of parental cells with protease from Streptomyces griseus, or any other non-lethal chemical agent tested. The results support prior indications that chromosomal marker exchange in S. acidocaldarius proceeds via conjugation, and further indicate that this conjugation can initiate quickly in dilute liquid suspension. The mating system of $S$. acidocaldarius thus appears physiologically distinct from that of Haloferax volcanii but perhaps similar to conjugational transfer of Sulfolobus plasmid pNOB8. The frequency of recombinants formed in these assays $\left(10^{-4}-10^{-5}\right.$ per c.f.u.) greatly exceeds the number of spontaneous forward mutational events per generation for biosynthetic genes in S. acidocaldarius. This suggests that chromosomal exchange has the potential to influence the genetic dynamics of natural Sulfolobus populations.

Keywords: geothermal environments, archaea, genetic exchange, cellular mechanism, conjugation

\section{INTRODUCTION}

Molecular phylogenetic analyses have shown that a group of diverse prokaryotes represents an evolutionary lineage distinct from that of bacteria. Members of this lineage, termed archaea (formerly 'archaeobacteria'; Woese et al., 1990), apparently share a non-bacterial common ancestor with eukaryotes (Brown \& Doolittle, 1995). As would be predicted from their great evol-

Abbreviation: MPN, most probable number. utionary age, the archaea exhibit unusual biochemical features and a remarkable ecological diversity (Jones $e t$ al., 1987). They are particularly noted for dominating habitats defined by extremely harsh conditions. The most halophilic (Jones et al., 1987), the most acidophilic (Schleper et al., 1995b) and the most thermophilic (Stetter et al., 1990) organisms known are, in each case, archaea. By the criterion of rRNA sequences, new yet uncultivated taxa of archaea appear to be abundant in milder, more extensive habitats such as subsurface ocean water (Hershberger et al., 1996). These results suggest that archaea make up a significant proportion of the 
earth's microbiota and represent some of the most primordial organisms yet identified by sequence analysis (Barns et al., 1994).

The extreme conditions which many archaea require for optimal growth, combined with their phylogenetic position relative to bacteria and eukaryotes, raise many questions regarding cellular function at the molecular level. Sulfolobus spp., for example, grow optimally at about $80^{\circ} \mathrm{C}$ and $\mathrm{pH} 3$; this combination of extremely high temperature and low $\mathrm{pH}$ efficiently denatures the macromolecules of mesophilic organisms. Thermostabilities of proteins and nucleic acids from Sulfolobus spp. and other thermophilic archaea have been studied in vitro by various research groups. However, properties of the organisms themselves raise many questions regarding cellular function at extremely high temperature which must be answered using direct, in vivo techniques. Development of genetic methods is especially strategic, and can be expected to depend heavily on identifying, analysing and exploiting natural genetic processes of these unusual prokaryotes.

Among thermophilic archaea, the greatest number of genetic processes occur in members of the genus Sulfolobus; for example, spontaneous mutation (Jacobs \& Grogan, 1997), UV-induced mutation (Wood et al., 1997) and photoreactivation (Grogan, 1997) have been studied in Sulfolobus acidocaldarius. Moreover, S. acidocaldarius spontaneously exchanges and recombines chromosomal genetic markers (Grogan, 1996a). This latter phenomenon seems to resemble the mating process of Haloferax volcanii (Mevarech \& Werczberger, 1985), an archaeon otherwise unrelated to $S$. acidocaldarius which grows optimally at about $40^{\circ} \mathrm{C}$ in concentrated $\mathrm{NaCl}$ solutions (Mullakhanbhai \& Larsen, 1975). In both cases, mixtures of stable auxotrophs form prototrophs only if live and genetically distinct cells are allowed to come into contact, but plasmid dependence, unidirectional transfer and entry exclusion have not been observed (Mevarech \& Werczberger, 1985; Rosenshine et al., 1989; Rosenshine \& Mevarech, 1991; Grogan, 1996a). This suggests that both of these archaeal exchange phenomena differ mechanistically from most examples of bacterial conjugation, which exhibit the latter three features (Clark \& Warren, 1979; Willets \& Skurray, 1980; Hopwood \& Kieser, 1993; Macrina \& Archer, 1993). It should be noted, however, that (i) a few examples of bacterial conjugation lack at least one of these 'classical' features, and (ii) unidirectional transfer of at least one genetic element, namely Sulfolobus plasmid pNOB8, has been observed in archaea (Schleper et al., 1995a).

Of the three known examples of conjugation among archaea, those of pNOB8 and $H$. volcanii have been characterized to limited extents cytologically, and the results indicate major differences with respect to the cell-cell interaction necessary for transfer. Plasmid pNOB8 can spread rapidly through liquid cultures of recipient cells even under continuous agitation (Schleper et al., 1995a), whereas agitation in liquid medium prevents and disrupts genetic exchange in $H$. volcanii (Rosenshine \& Mevarech, 1991). Indeed, H. volcanii mating requires incubation of a heavy film of cells on a solid support (Mevarech \& Werczberger, 1985) and seems complete only when these physically stable contacts are maintained for several hours (Rosenshine \& Mevarech, 1991).

Both of these situations have precedents among bacteria. Efficient DNA transfer between bacteria in liquid media, exemplified by the Escherichia coli fertility (F) plasmid, depends upon specific molecular recognition between donor and recipient cells that is mediated by surface proteins, i.e. the pili of Gram-negative bacteria (Clark \& Warren, 1979; Willets \& Skurray, 1980) or the adhesins of Gram-positive cocci (Clewell, 1993). The resulting high affinity of donor and recipient cells for each other causes rapid pairing of the two cell types upon mixing, effectively synchronizing genetic exchange and facilitating experimental analysis of its progress. Transfer of pNOB8 seems consistent with this type of conjugation, in the sense that mixed aggregates are reported to form rapidly when donor and recipient cells are combined (Schleper et al., 1995a). In contrast, certain bacterial plasmids transfer only when donor and recipient cells are incubated in contact as a film on a solid support, in some cases for periods of time corresponding to several cell divisions (Hopwood \& Kieser, 1993; Macrina \& Archer, 1993). This requirement, which among Gramnegative bacteria correlates with the absence of a particular type of pilus (Wilkins, 1995), apparently reflects failure to establish cell pairs with high affinity, despite the full functioning of subsequent DNA transfer processes. Transfer of chromosomal markers between $H$. volcanii strains seems to resemble this latter bacterial situation.

The available data (Grogan, 1996a) do not indicate whether exchange of chromosomal markers in S. acidocaldarius more resembles the pNOB8 system or the $H$. volcanii system with respect to the physical and cellular parameters required for effective transfer. As a means to better understand its mechanism and to further define its practical aspects, we assayed marker exchange in $S$. acidocaldarius under a variety of conditions. The results suggest that, although chromosomal markers are exchanged and recombined as in $H$. volcanii, the cellular properties of $S$. acidocaldarius mating more closely resemble those of Sulfolobus plasmid pNOB8.

\section{METHODS}

Strains and growth conditions. The pyrimidine auxotrophs DG29 (pyrD1) and DG38 (cbp-2) were used in most experiments. Typical revertant frequencies for these two strains are about $3 \times 10^{-7}$ revertants per c.f.u. (Wood et al., 1997). In some experiments, the independent pyrF mutants MR27, MR39 and MR41 were used as parental strains to eliminate the potential of cross-feeding. Typical revertant frequencies for these strains are less than about $1 \times 10^{-7}$ revertants per c.f.u.

All cultures to be mated were grown from a single colony in 
xylose/tryptone/uracil ('XTura') medium (Jacobs \& Grogan, 1997) with continuous agitation at $80^{\circ} \mathrm{C}$, unless otherwise noted. Cultures were harvested at cell densities less than about $4 \times 10^{8}$ cells $\mathrm{ml}^{-1}$. Growth medium was removed by pelleting the cells, carefully decanting the supernatant, and resuspending the cell pellet in Sulfolobus dilution (Sdil) buffer (Grogan, 1996a) to achieve the desired cell density $\left(1 \times 10^{9}\right.$ cells $\mathrm{ml}^{-1}$, unless otherwise noted).

Mating assays on solid medium. Cells $\left(5 \times 10^{7}\right.$ of each strain, unless otherwise noted) were mixed and spread on $6-\mathrm{cm}$ diameter plates of Sdil buffer solidified with gellan gum and incubated for $20 \mathrm{~h}$ at $75^{\circ} \mathrm{C}$. The cells were then quantitatively recovered from the plate surface by resuspension in three successive $1 \mathrm{ml}$ aliquots of Sdil, using a sterile glass spreader, and plated to enumerate viable and recombinant cells (see below). Corrections for mating events subsequent to incubation on these plates were provided by control plates in which the two parental strains were deposited on separate sectors of one such plate but were otherwise processed in the same manner, as described previously (Grogan, 1996a).

The effects of cell density under these conditions were determined in two ways. The first was by varying the number of cells mated (from $1 \times 10^{7}$ to $4 \times 10^{8}$ of each parental strain) on an area of $10 \mathrm{~cm}^{2}$. The other was by varying the surface area (from 0.3 to $20 \mathrm{~cm}^{2}$ ) upon which $5 \times 10^{7}$ cells of each parental strain were mated.

The effect of incubation time on solid medium was determined by preparing a series of identical mating and control plates and incubating them all at $75^{\circ} \mathrm{C}$. One mated and one control plate were then withdrawn at various times from 1 to $30 \mathrm{~h}$, and the viable and recombinant c.f.u. of each were enumerated.

The expected number of random cell-cell contacts on solid media was estimated using the Poisson distribution of nearest neighbours in two dimensions, $P(d)=1-\mathrm{e}^{-\pi \rho d^{2}}$, where $P(d)$ is the probability that two or more randomly dispersed points will lie within a distance $d$ of each other, and $\rho$ is the mean density of particles on the surface. For our purpose, $d$ was set equal to $1 \mu \mathrm{m}$, which approximates the diameter of an $S$. acidocaldarius cell, and thus the centre-to-centre distance of two cells in contact.

Mating assays in liquid medium. The effects of cell density and of parental cell ratios were determined by incubating mixed suspensions of cells in Sdil buffer in 13-mm-diameter glass tubes containing $0.5 \mathrm{ml}$ solidified Sdil. Correction for subsequent mating events was made by controls in which pure parental suspensions were similarly incubated and then combined at $22^{\circ} \mathrm{C}$ shortly before enumeration. Cell density was varied either by varying the volume of Sdil buffer in which $8 \times 10^{6}$ cells were suspended [from nearly zero (film dried on surface of solid medium) to $1.5 \mathrm{ml}$ ] or varying the number of cells resuspended in $1 \mathrm{ml}$ Sdil (from $4.8 \times 10^{8}$ to $6.4 \times 10^{6}$ ). In all other liquid matings, cells suspended in Sdil were simply combined in 13-mm-diameter glass culture tubes and treated as described in Results.

Enumeration. Unless otherwise noted, recombinant frequencies are $\mathrm{Pyr}^{+}$colonies per $10^{6}$ c.f.u. plated. Aliquots $(50-100 \mu \mathrm{l})$ of undiluted cell suspensions were plated on xylose/glutamine/casein hydrolysate medium and incubated for 1 week at $75^{\circ} \mathrm{C}$ to select $\mathrm{Pyr}^{+}$recombinants. The suspensions were also diluted in Sdil and plated on solid XTura medium to enumerate c.f.u. In one series of experiments, $\mathrm{Pyr}^{+}$recombinants and total c.f.u. were estimated by the most probable number (MPN) method using liquid media.
(For this purpose, Dextrin-10 (Serva) was substituted for Dxylose as the primary carbon source.) Cell mixtures $(0.2 \mathrm{ml}$ each) were diluted serially in U-bottom polystyrene microdilution plates; growth was scored after incubation for 1 week at $75^{\circ} \mathrm{C}$.

\section{RESULTS}

\section{Effect of cell density on efficiency of plate matings}

To manipulate and analyse genetic exchange in $S$. acidocaldarius, we were interested in identifying conditions that interfere with the process. The initial hypothesis of this study was that, like $H$. volcanii, $S$. acidocaldarius conjugation should require cell-cell contacts to be established and stabilized on the surface of solid media. One prediction of this hypothesis is that conjugation should be effectively prevented even on solid media (which are used to enumerate recombinants) if mixtures were plated at sufficiently low cell densities. Results of prior plate-mating assays and their controls (Grogan, 1996a) seemed consistent with this hypothesis.

To measure the hypothesized density dependence, $S$. acidocaldarius pyrimidine (uracil) auxotrophs DG29 and DG38 were mixed and incubated on solid, nonnutritive medium as described previously (Grogan, 1996a), except that the mean cell density was varied nearly 600 -fold, i.e. from $6 \times 10^{5}$ to $3.5 \times 10^{8}$ cells cm $\mathrm{cm}^{-2}$. The efficiency of genetic exchange, measured as the ratio of $\mathrm{Pyr}^{+}$recombinants to c.f.u., showed relatively little dependence on cell density, either overall or within a given trial (Fig. 1). (For reference, mean cell densities

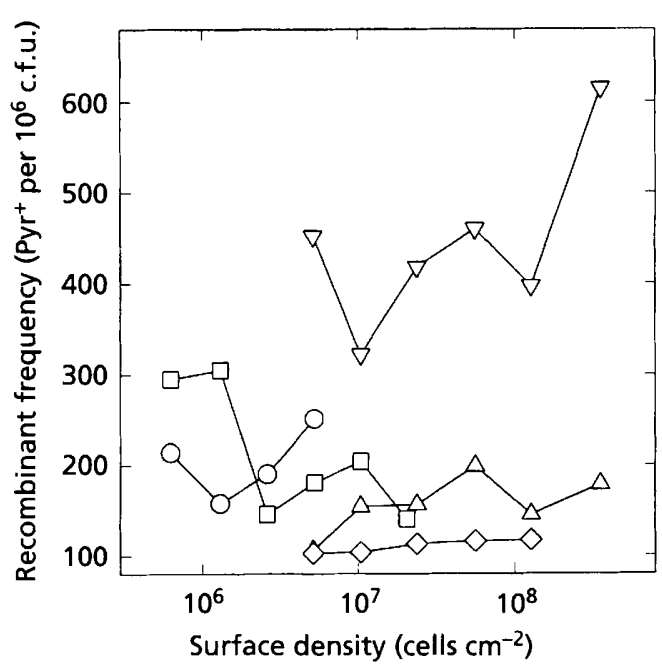

Fig. 1. Efficiency of genetic exchange as a function of plating density. Strains DG29 and DG38 were mated on solid, nonnutritive medium; the surface density of parental cells was varied as described in Methods. Each symbol represents the mean of two determinations corrected for reversion plus mating events subsequent to the above incubation. Each symbol type (connected by lines) represents an independent trial. Recombinant frequencies are expressed as $\mathrm{Pyr}^{+}$colonies per $10^{6}$ c.f.u. (note the compressed, logarithmic scale for cell density). 
Table 1. Effect of cell compaction on the efficiency of genetic exchange

Matings were performed for $20 \mathrm{~h}$ at $75^{\circ} \mathrm{C}$ in glass tubes containing solid medium (see Methods), using $1 \times 10^{8}$ cells of each parental strain. In most tubes (see first footnote below), the cells were suspended in a total volume of $1 \mathrm{ml}$.

\begin{tabular}{|lcc|}
\hline Mating conditions* & $\begin{array}{c}\text { Corrected } \\
\text { recombinant } \\
\text { frequencies } \dagger\end{array}$ & $\begin{array}{c}\text { 'Background' } \\
\text { subtracted } \neq\end{array}$ \\
\hline Film on surface & 63,153 & 40 \\
Submerged cell pellet & 89,75 & 32 \\
Non-agitated suspension & 123,33 & 33 \\
Infrequently agitated & 37,50 & 30 \\
Continuously agitated & 66,117 & 18 \\
\hline
\end{tabular}

* 'Non-agitated' treatment corresponds to standard conditions used in other experiments. Modified conditions were: 'film on surface', cells were concentrated, deposited as a film on the surface of the solid medium, and left dry (as on a plate); 'submerged cell pellet', cells were pelleted against the solid medium from a mixed suspension $(1 \mathrm{ml})$ and not resuspended; 'infrequently agitated', cell suspensions were vigorously agitated by hand at three different times separated by intervals of several hours; 'continuously agitated', cell suspensions were rotated at about 10 r.p.m., as described in Methods.

† Values are $\mathrm{Pyr}^{+}$colonies per $10^{6}$ c.f.u. (duplicate determinations) after correction for controls (see footnote below).

$\ddagger$ Controls for recombination not attributable to the experimental conditions. The parental strains were incubated separately under the above experimental conditions, and then were combined at $22{ }^{\circ} \mathrm{C}$ shortly before plating to enumerate recombinants. The values in this column have been subtracted from the recombinant frequencies of duplicate determinations to yield the corrected recombinant frequencies shown in the preceding column.

below about $7 \times 10^{6} \mathrm{~cm}^{-2}$ should give less than $10 \%$ cells in contact on the plate surface if randomly distributed.) The results of Fig. 1 therefore do not support the hypothesis that $S$. acidocaldarius mating depends on the random formation of cell-cell contacts by adsorption of dense films of cells to an interface.

In an alternative test of the role of cell density, we compared the effect of incubating cells under various states of compaction. Matings were performed in tubes containing solid medium and $1 \times 10^{8}$ cells of each parental strain. At one extreme, cells were deposited as a film on the dry surface (about $0.8 \mathrm{~cm}^{2}$ ) of the medium; at the other extreme, cells were suspended in $1 \mathrm{ml}$ buffer in contact with the solid medium and kept continuously in suspension by rotating the tubes about an axis inclined $15^{\circ}$ from horizontal. Intermediate treatments were: cell pellets incubated under $1 \mathrm{ml}$ buffer, non-agitated $1 \mathrm{ml}$ suspensions, and $1 \mathrm{ml}$ suspensions vigorously shaken intermittently during incubation. All these treatments yielded comparable efficiencies of genetic exchange (Table 1), indicating that genetic exchange in S. acidocaldarius is not assisted by immobilization or dense packing of cells.

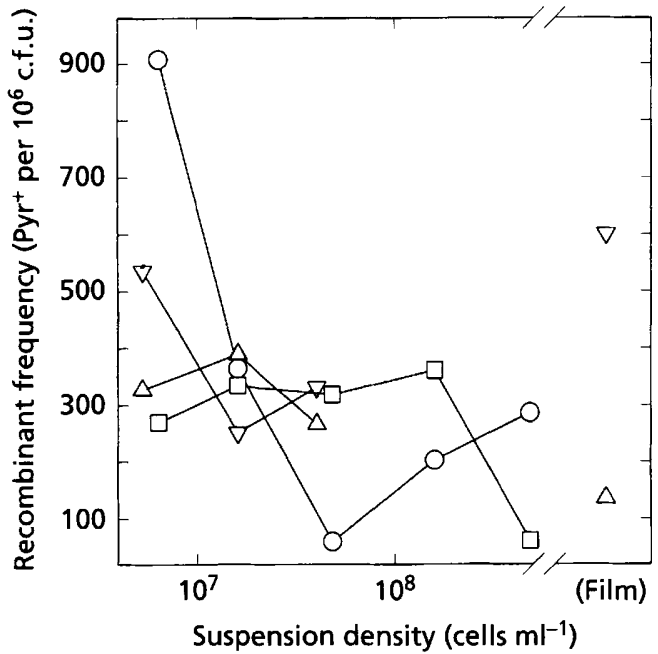

Fig. 2. Efficiency of genetic exchange in liquid medium. Cells were mated as non-agitated suspensions in Sdil buffer; cell density was varied as described in Methods. Other conditions were as for Fig. 1.

When cell mixtures were mated at $75^{\circ} \mathrm{C}$ in liquid suspension, the efficiency of recombinant formation was not a decreasing function of cell density; in fact, increases were seen at the low cell densities (Fig. 2). Moreover, we noted that in some experiments (e.g. Table 1) 'non-mated' controls, which were subtracted as corrections in calculating the effects of the various test conditions, had yielded $\mathrm{Pyr}^{+}$frequencies approaching those of the mated mixtures and about 100 times the typical revertant frequency of these strains (Table 1). Since these controls represent pure parental suspensions combined only shortly before enumeration of recombinants, these results raised the possibility that cell-cell contacts not only form in liquid suspension, but form rapidly at $22^{\circ} \mathrm{C}$.

In attempts to estimate the kinetics of this apparent room-temperature initiation of conjugation, we combined aliquots of parental cell suspensions in glass culture vessels, incubated the mixtures for various times at either 22 or $75^{\circ} \mathrm{C}$, and then enumerated $\mathrm{Pyr}^{+}$ recombinants and c.f.u. by plating. The results (Table 2) suggested that the apparent initiation of conjugation at $22^{\circ} \mathrm{C}$ occurred very quickly, i.e. during the few minutes in which a mixed suspension was sampled and plated on solid medium. Significant increases above this basal level of conjugation were seen only after overnight incubation at $75{ }^{\circ} \mathrm{C}$ (Table 2), suggesting the need for biosynthesis or other metabolism to yield yet more recombinants. Supplementation of similar mating mixtures with uracil did not decrease the $\mathrm{Pyr}^{+}$frequency, suggesting that revertants are not selected during prolonged incubation at $75^{\circ} \mathrm{C}$.

The rapidity of the presumed cell pairing at room temperature was unexpected, and prompted us to consider alternative explanations. In principle, we could not categorically eliminate initiation of conjugation on 
Table 2. Genetic exchange efficiency as a function of time in mixed liquid suspensions

A total of $10^{7}$ cells each of strains DG29 and DG38 were combined in a volume of $1.0 \mathrm{ml}$ in $13-\mathrm{mm}$ diameter glass tubes $\left(22^{\circ} \mathrm{C}\right.$ incubation) or screw-cap vials $\left(75^{\circ} \mathrm{C}\right.$ incubation). After the indicated times, aliquots were withdrawn for enumeration of c.f.u. and recombinants.

\begin{tabular}{|c|c|c|c|c|}
\hline \multirow{3}{*}{$\begin{array}{l}\text { Time of } \\
\text { incubation }(\mathbf{h})\end{array}$} & \multicolumn{4}{|c|}{$\mathrm{Pyr}^{+}$per $10^{6}$ c.f.u. ( $\%$ initial value) } \\
\hline & \multicolumn{2}{|c|}{$22{ }^{\circ} \mathrm{C}$} & \multicolumn{2}{|c|}{$75^{\circ} \mathrm{C}$} \\
\hline & Trial 1 & Trial 2 & Trial 1 & Trial 2 \\
\hline $0^{*}$ & $158(100)$ & $31(100)$ & $121(100)$ & $50(100)$ \\
\hline 0.5 & $29+(18)$ & $17(53)$ & $53+(44)$ & $31(62)$ \\
\hline $1 \cdot 0$ & $26(17)$ & $34+(108)$ & $107(88)$ & $62+(125)$ \\
\hline 22 & $44(28)$ & $20(65)$ & $318(262)$ & $143(288)$ \\
\hline
\end{tabular}

* For $0 \mathrm{~h}$ treatments, the actual time elapsed between initial mixing and full absorption of the liquid into the plates was about $2 \mathrm{~min}$.

†In these cases, c.f.u. were taken to be the mean of the previous and subsequent time points.

solid media, since our mating assays for S. acidocaldarius, as well as those for H. volcanii (and for microorganisms generally), involve the prolonged incubation of cell mixtures on selective plates. However, the hypothesis that many cell contacts first form on the selective plates seemed unlikely in view of the low densities, i.e. a few million cells spread over about $30 \mathrm{~cm}^{2}$ of selective medium. As predicted by random distribution, only $0.003 \%$ of the cells would be in contact with another cell under these conditions. Furthermore, density dependence of cell contacts on plates at cell densities comparable to those used in the present study has been used to prevent initiation of conjugation of Enterococcus faecalis (Ike \& Clewell, 1984). In conjugational transfer of E. faecalis plasmid pAD1, donor cells require prior induction by pheromone to become fully effective in conjugating in liquid medium, whereas conjugation in filter matings requires no induction (Clewell, 1993). Plating of uninduced donorrecipient mixtures yielded a conjugation frequency of $10^{-5}$ the normal frequency (Ike \& Clewell, 1984), which argues that pair formation by random placement of $E$. faecalis cells on the plate surface was negligible. Our results with $S$. acidocaldarius thus suggested that the cell-cell associations presumed to initiate conjugation formed before or during plating.

In addition to the quantitative considerations above, we were able to experimentally support the hypothesis that conjugation occurs in liquid suspension, using an MPN (serial dilution) method. Washed cells of $\mathrm{Pyr}^{-}$parental strains were combined in selective liquid medium at an initial cell density of about $3 \times 10^{7}$ cells $\mathrm{ml}^{-1}$. After brief (30-60 min) incubation at $22^{\circ} \mathrm{C}$, five such mixed suspensions were diluted to extinction in selective medium to enumerate $\mathrm{Pyr}^{+}$recombinants, and in non-selective medium to enumerate viable cells. Controls included (i) otherwise identical dilution series of single strains only, and (ii) aliquots of the dilution series plated on solid
Table 3. Assays of genetic exchange in liquid medium

Washed cell suspensions were kept separate or combined as indicated; enumeration was by dilution in microdilution dishes (MPN) or by plating. The frequency of $\mathrm{Pyr}^{+}$clones is expressed per $10^{6}$ c.f.u.

\begin{tabular}{|cccc|}
\hline Trial & Strain(s) tested & $\begin{array}{c}\mathbf{P y r}^{+} \text {frequency } \\
\text { (MPN) }\end{array}$ & $\begin{array}{c}\mathbf{P y r}^{+} \text {frequency } \\
\text { (plating) }\end{array}$ \\
\hline $1^{*}$ & DG29 & $2 \cdot 300$ & 5.00 \\
& DG38 & 0.670 & $<0.67$ \\
& DG29 $\times$ DG38 & 63.000 & 66.00 \\
2 & DG29 & $141.000 \dagger$ & 0.70 \\
& DG38 & $<0.025$ & $<0.60$ \\
& DG29 $\times$ DG38 & $400.000 \ddagger$ & $715.00 \ddagger$ \\
\hline
\end{tabular}

"In this trial, c.f.u. were estimated from absorbance readings of washed suspensions.

† The MPN method overestimated reversion frequency of strain DG29 due to residual growth in selective media, which is characteristic of the pyrD1 allele. A more accurate estimate of reversion is given by plating.

$\ddagger$ Mean of duplicate determinations.

media. The results (Table 3 ) show that enumeration by dilution in liquid media yielded recombinant frequencies comparable to those observed using plates. Growth at the end points of dilutions in selective medium could not be attributed to cross-feeding between the mutants; over $70 \%$ of the c.f.u. from these wells were prototrophs, compared with no (i.e. $<2 \%$ ) prototrophs recovered from the non-selective dilution series. Furthermore, similar results (not shown) were obtained with pairwise combinations of the three pyrF strains MR27, 39 and 41, which cannot cross-feed. The results of Table 3 thus demonstrate that efficient marker transfer does not require plating of $S$. acidocaldarius. 


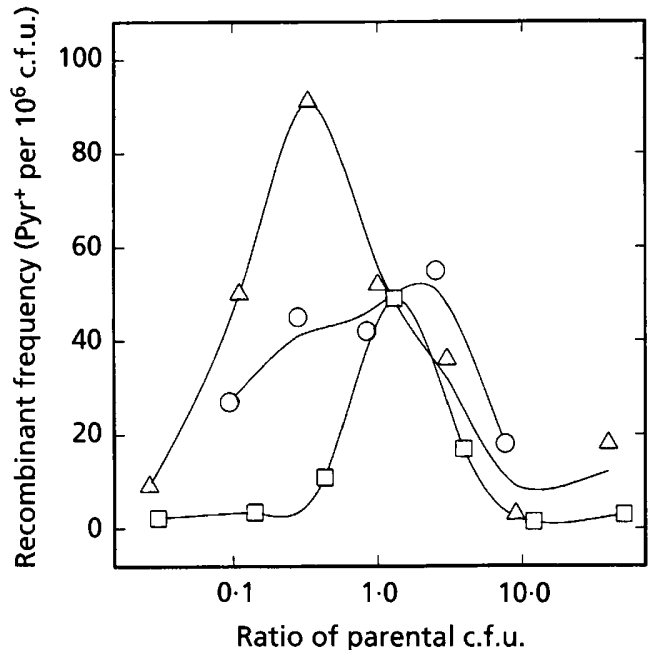

Fig. 3. Efficiency of genetic exchange as a function of parental cell ratio. Non-agitated liquid suspensions $(0.2 \mathrm{ml}$ containing $2 \times 10^{6}$ cells total) were mated as described in Methods; the proportion of either parental strain was varied from 0 to $100 \%$. Total c.f.u. after incubation, as well as corrections for reversion, were calculated from the $0 / 100 \%$ (pure parental) suspensions in each series. O, DG29 $\times$ DG38; $\square$, MR27 $\times$ MR41; $\triangle$, MR39 $\times$ MR41.

\section{Additional tests of a conjugational mechanism}

We investigated whether the apparent initiation of genetic exchange in liquid suspension exhibited two properties expected of conjugation, i.e. (i) requirement for contacts between cells of different genotype, and (ii) insensitivity to extracellular DNase. In the first series of tests, we conducted mating assays in liquid, keeping the total number of cells constant but varying the ratio of parental strains up to 200 -fold. The resulting recombinant frequencies were distributed in roughly symmetrical manner about maxima occurring near a ratio of 1 (Fig. 3). This pattern is expected when at least one cell of each parental type is required to form a recombinant (Maloy et al., 1994).

To test the effect of DNase, we took advantage of the initiation of genetic exchange in Sdil suspensions at $22{ }^{\circ} \mathrm{C}$. DNase I was fully active under these conditions, as indicated by spectrophotometric assay, but exerted no inhibitory effect on genetic exchange (Table 4). These results provide additional evidence that chromosomal marker exchange in $S$. acidocaldarius proceeds via conjugation (Grogan, 1996a).

\section{Tests for conditions that prevent genetic exchange}

In further attempts to control, and thereby experimentally analyse, the initiation of conjugation, various chemical agents were tested for their effect on marker exchange initiated in liquid suspension at $22^{\circ} \mathrm{C}$. The low-specificity protease from Streptomyces griseus ('Pronase') was tested because proteases destroy the
Table 4. Effect of hydrolytic enzymes on efficiency of genetic exchange

Mixed suspensions $\left(5 \times 10^{7}\right.$ cells of each parental strain) were incubated for $30 \mathrm{~min}$ at $22{ }^{\circ} \mathrm{C}$ in glass tubes before enumeration of c.f.u. and $\mathrm{Pyr}^{+}$recombinants.

\begin{tabular}{|c|c|c|}
\hline \multirow[t]{2}{*}{ Treatment } & \multicolumn{2}{|c|}{$\begin{array}{c}\text { Recombinant } \\
\text { frequency } \\
\left(\mathrm{Pyr}^{+} \text {per } 10^{6} \text { c.f.u. }\right)\end{array}$} \\
\hline & Trial 1 & Trial 2 \\
\hline \multicolumn{3}{|l|}{ DNase $^{*}$} \\
\hline No additions & 41,58 & \\
\hline Serum albumin & 38,44 & 41 \\
\hline DNase I & 93,90 & 80 \\
\hline \multicolumn{3}{|l|}{ Pronase $†$} \\
\hline Cells pre-mixed, no additions & 5 & 59 \\
\hline Cells post-mixed, no additions & 38 & 60 \\
\hline Cells pre-mixed, $1 \%(\mathrm{w} / \mathrm{v})$ Pronase & 343 & 155 \\
\hline $1 \%(\mathrm{w} / \mathrm{v})$ Pronase, cells post-mixed & 108 & 138 \\
\hline Cells pre-mixed, $2 \%(\mathrm{w} / \mathrm{v})$ Pronase & 83 & 149 \\
\hline $2 \%(\mathrm{w} / \mathrm{v})$ Pronase, cells post-mixed & 84 & 456 \\
\hline
\end{tabular}

* DNase or bovine serum albumin was added to a final concentration of $1 \%(\mathrm{w} / \mathrm{v})$ before suspensions were combined.

$\dagger$ 'Pre-mixed' indicates that suspensions were combined before Pronase treatment, whereas 'post-mixed' suspensions were first treated separately with Pronase before being combined. Pronase treatment of cells was for $2 \mathrm{~h}$ at $40^{\circ} \mathrm{C}$ in both cases.

cell-surface determinants of high-affinity conjugation in bacteria (Clewell, 1985). In intact S. acidocaldarius cells, Pronase digests externally exposed membrane glycoproteins but does not detectably affect the S-layer subunits (Grogan, 1996b). Predigestion of parental cells with Pronase did not interfere with genetic exchange under our conditions (Table 4). Other additives, primarily salts, buffers at various $\mathrm{pH}$ values and polymers, also failed to reproducibly prevent the initiation of genetic exchange (Table 5).

\section{DISCUSSION}

The exchange and recombination of auxotrophic markers among $S$. acidocaldarius strains is, to our knowledge, only the second example of chromosomal DNA transfer so far identified among archaea, and one of only three examples of archaeal conjugation of any type. In contrast to the mating phenomenon of $H$. volcanii, which appears to require the formation and physical stabilization of cell-cell contacts on solid supports (Mevarech \& Werczberger, 1985; Rosenshine \& Mevarech, 1991), exchange of chromosomal markers in $S$. acidocaldarius seemed to initiate quickly in liquid media. This was indicated by the efficient recovery of recombinants from dilute suspensions mixed at $22{ }^{\circ} \mathrm{C}$ and rapidly plated, and by the detection of recombinants 


\section{Table 5. Efficiency of genetic exchange in the presence of additives}

Cells of the parental strains were suspended in Sdil buffer supplemented as indicated $\left({ }^{\circ} \mathrm{H}_{2} \mathrm{O}\right.$ ' cells were washed and resuspended in distilled water) before being combined at $22^{\circ} \mathrm{C}$. After 20 min, recombinants and c.f.u. were enumerated; recombinant frequency values are the means of duplicate determinations. EDTA $(10 \mathrm{mM})$ was also tested and found to be unable to prevent recombination, but its effect on subsequent growth interfered with the quantitative assay of genetic exchange.

\begin{tabular}{|c|c|c|c|}
\hline \multirow[t]{2}{*}{ Mating conditions } & \multicolumn{3}{|c|}{$\mathrm{Pyr}^{+}$per $10^{6}$ c.f.u. ( $\%$ of control) } \\
\hline & Trial 1 & Trial 2 & Trial 3 \\
\hline Standard & $28(100)$ & $131(100)$ & $25(100)$ \\
\hline $\mathrm{H}_{2} \mathrm{O}$ only & & & $10(40)$ \\
\hline \multicolumn{4}{|l|}{$0.1 \mathrm{M}$ sodium acetate } \\
\hline $\mathrm{pH} 4.8$ & $41(146)$ & & \\
\hline \multirow{2}{*}{\multicolumn{4}{|c|}{$\begin{array}{l}0.02 \mathrm{M} \text { potassium } \\
\text { phosphate } / \text { malate }\end{array}$}} \\
\hline & & & \\
\hline $\mathrm{pH} 2 \cdot 6$ & $<0.5(<2)$ & $63(48)$ & $22(88)$ \\
\hline $\mathrm{pH} 3 \cdot 1$ & & $198(151)$ & $9(36)$ \\
\hline $\mathrm{pH} 3.6$ & & $151(115)$ & $23(92)$ \\
\hline $\mathrm{pH} 5 \cdot 2$ & $35(125)$ & & \\
\hline $0 \cdot 2 \mathrm{M} \mathrm{KCl}$ & $<0 \cdot 1(<4)$ & $52(40)$ & \\
\hline $0 \cdot 2 \mathrm{M} \mathrm{MgSO}_{4}$ & $120(429)$ & & \\
\hline $10 \%(\mathrm{v} / \mathrm{v})$ PEG 400 & $26(93)$ & & \\
\hline $0 \cdot 1 \%$ gellan gum & & $113(86)$ & \\
\hline
\end{tabular}

in dilute cell suspensions which were never plated. Formation of recombinants was not prevented or reversed by any of several chemical agents, including DNase I and broad-specificity protease. We have thus failed so far to identify a practical method of blocking genetic exchange once two cell suspensions have been combined. Although this failure provides evidence of a specific and effective mode of cell pairing, it also limits our ability to dissect the mechanism of transfer in the way in which bacterial conjugation has been analysed (Clark \& Warren, 1979; Willets \& Skurray, 1980; Macrina \& Archer, 1993; Clewell, 1993).

In their study of Sulfolobus plasmid pNOB8, Schleper $e t$ al. (1995a) used genomic DNA analysis to demonstrate cell-cell transfer in liquid culture, fluorescence microscopy to detect rapid formation of mixed cell aggregates of donor and recipient strains, and scanning electron microscopy to suggest the formation of cytoplasmic bridges within these aggregates. Our data seem generally consistent with a similar mechanism for $S$. acidocaldarius chromosomal transfer, but the genetic assay is much more sensitive. As a result, only about $0.03 \%$ of the cells in an S. acidocaldarius mixture must conjugate to yield the recombinant frequencies that we observed. This minimum is about $1 / 100$ th of the frequency of cell pairs $(4 \%)$ found in growing Sulfolobus cultures, the majority of which probably represent cell division intermediates (Poplawski \& Bernander, 1997). Our own preliminary microscopy of washed DG29 and DG38 cells estimates pairs and aggregates to represent $7 \%$ of particles in suspension, and they are not more abundant in mixtures (data not shown). In contrast to pNOB8 transfer, the intrinsic genetic exchange mechanism of $S$. acidocaldarius may thus prove impractical to analyse microscopically.

Whatever the actual frequency of pairing, the molecular architecture of $H$. volcanii and Sulfolobus cell envelopes implies that conjugation involves interaction between outer faces of the S-layers (Baumeister \& Lembcke, 1992), which seems consistent with experimental observations. Bacterial S-layers may mediate specific cell-cell attachment, as suggested by the spontaneous pairing of Deinococcus S-layers in perfect register at their extracellular faces (Baumeister \& Hegerl, 1986). Similarly, intact S-layer sacculi purified from S. acidocaldarius by detergent extraction spontaneously aggregate in suspension. This clumping, which can interfere with the use of S-layer fragments as nanometre-scale surface-patterning templates (see Douglas et al., 1992), can only be avoided through particular growth and purification conditions ( $\mathrm{J}$. Moore, personal communication). Our observation that $2 \mathrm{~h}$ Pronase treatment did not decrease fertility of $S$. acidocaldarius may also be significant, since $S$-layer subunits are the only externally exposed cell envelope proteins of $S$. acidocaldarius known to be completely resistant to Pronase digestion (Grogan, 1996b).

Taken together, our results are consistent with the hypothesis that $S$. acidocaldarius cultures contain a proportion (apparently small) of cells able to rapidly form cell-cell associations in dilute liquid suspension, leading eventually to chromosomal exchange and homologous recombination. This hypothesis raises a series of mechanistic questions, and a variety of physiological 
parameters, which have yet to be evaluated, apparently affect the efficiency of genetic exchange. The recombinant frequency for a pair of strains under defined conditions varied considerably among different trials (e.g. Fig. 1 ; Table 5). As a function of growth phase, we have found the fertility of cultures to be highest at the lowest cell densities, gradually declining to about $10 \%$ of its original value in stationary phase (data not shown). In other experiments, parental cells were incubated separately at $75{ }^{\circ} \mathrm{C}$ on solid non-nutrient medium before being combined. Under these conditions, fertility declined several-fold over a period of $30 \mathrm{~h}$. This decline, coupled with a concomitant increase in recombinants from mixtures similarly incubated (data not shown), helps to explain the fact that, in prior studies, control plates yielded significantly lower recombinant frequencies than mated mixtures (Grogan, 1996a).

The frequency and apparently robust nature of chromosomal marker exchange in $S$. acidocaldarius has implications for gene flow and evolutionary dynamics of Sulfolobus populations in geothermal habitats. The range of conditions tested in the present study was constrained by our focus on straightforward laboratory techniques, but it suggests that the exchange of chromosomal genes can be efficient and does not have requirements that preclude it in natural habitats of Sulfolobus. [A similar conclusion could be drawn for transfer of pNOB8 (Schleper et al., 1995a).] The frequencies of $10^{-5}-10^{-4} \mathrm{Pyr}^{+}$recombinants per c.f.u. typically observed in the present study greatly exceed the rate of spontaneous mutation in $S$. acidocaldarius, which was recently estimated to be $1-3 \times 10^{-7}$ mutational events per cell division for the $p y r E$ and $p y r F$ genes (Jacobs \& Grogan, 1997). Although marker exchange is probably less frequent in nature than under our optimized laboratory conditions, recombination rates need not be this high to exert an effect on genetic properties of populations. Theoretical models predict that much lower rates of recombination can confer sexual character upon suitable populations of prokaryotes (Cohan, 1994; Maynard Smith, 1994). It is interesting to speculate that the enhanced genetic diversity due to out-crossing may be sufficiently advantageous so as to maintain chromosomal exchange in natural populations of $S$. acidocaldarius. [It must be borne in mind, however, that demonstration of spontaneous genetic exchange under laboratory conditions does not guarantee its predominance in nature; bacteria known to exchange genes in laboratory experiments have apparently clonal population structures in nature (Maynard Smith et al., 1993).] Alternatively, conjugation may primarily benefit $S$. acidocaldarius as a mechanism of DNA repair, the genetic consequences of which, though beneficial, are indirect and secondary (Bernstein et al., 1985).

\section{ACKNOWLEDGEMENTS}

We thank A. Russell for technical help with certain experiments and M. Reilly for the stable pyrF mutants. This work was supported by grant N00014-94-I-0393 from the US Office of Naval Research.

\section{REFERENCES}

Barns, S. M., Fundyga, R., Jeffries, M. \& Pace, N. R. (1994). Remarkable archaeal diversity detected in a Yellowstone National Park hot spring environment. Proc Natl Acad Sci USA 91, 1609-1613.

Baumeister, W. \& Hegerl, R. (1986). Can S-layers make bacterial connexons? FEMS Microbiol Lett 36, 119-125.

Baumeister, W. \& Lembcke, G. (1992). Structural features of archaebacterial cell envelopes. J Bioenerg Biomembr 24, 567-575.

Bernstein, H., Byerly, H., Hopf, F. \& Michod, R. (1985). DNA repair and complementation: the major factors in the origin and maintenance of sex. In The Origin and Evolution of Sex, pp. 29-45. Edited by H. Halvorson \& A. Monroy. New York: Alan R. Liss.

Brown, J. R. \& Doolittle, W. F. (1995). Root of the universal tree of life based on ancient aminoacyl-tRNA synthetase gene duplications. Proc Natl Acad Sci USA 92, 2441-2445.

Clark, A. J. \& Warren, G. J. (1979). Conjugal transmission of plasmids. Annu Rev Genet 13, 99-125.

Clewell, D. B. (1985). Sex pheromones, plasmids, and conjugation in Streptococcus faecalis. In The Origin and Evolution of Sex, pp. 3-28. Edited by H. Halvorson \& A. Monroy. New York: Alan R. Liss.

Clewell, D. B. (1993). Sex pheromones and the plasmid-encoded mating response in Enterococcus faecalis. In Bacterial Conjugation, pp. 349-367. Edited by D. B. Clewell. New York: Plenum.

Cohan, F. M. (1994). Genetic exchange and evolutionary divergence in prokaryotes. Trends Ecol Evol 9, 175-180.

Douglas, K., Devaud, G. \& Clark, N. A. (1992). Transfer of biologically derived nanometer-scale patterns to smooth substrates. Science 257, 642-644.

Grogan, D. W. (1996a). Exchange of genetic markers at extremely high temperatures in the archaeon $S$. acidocaldarius. J Bacteriol 178, 3207-3211.

Grogan, D. W. (1996b). Organization and interactions of cell envelope proteins of the extreme thermoacidophile Sulfolobus acidocaldarius. Can J Microbiol 42, 1163-1171.

Grogan, D. W. (1997). Photoreactivation in an archaeon from geothermal environments. Microbiology 143, 1071-1076.

Hershberger, K. L., Barns, S., Reysenbach, A.-L., Dawson, S. \& Pace, N. (1996). Wide diversity of Crenarchaeota. Nature 384, 420.

Hopwood, D. A. \& Kieser, T. (1993). Conjugative plasmids of Streptomyces. In Bacterial Conjugation, pp. 293-311. Edited by D. B. Clewell. New York: Plenum.

Ike, Y. \& Clewell, D. B. (1984). Genetic analysis of the pAD1 pheromone response in Streptococcus faecalis, using transposon Tn917 as an insertional mutagen. J Bacteriol 158, 777-783.

Jacobs, K. L. \& Grogan, D. W. (1997). Rates of spontaneous mutation in an archaeon from geothermal environments. $J$ Bacteriol 179, 3298-3303.

Jones, W. J., Nagle, D. P., Jr \& Whitman, W. (1987). Methanogens and the diversity of Archaebacteria. Microbiol Rev 51, 135-177.

Macrina, F. L. \& Archer, G. L. (1993). Conjugation and broad host range plasmids in streptococci and staphylococci. In Bacterial Conjugation, pp. 313-329. Edited by D. B. Clewell. New York: Plenum.

Maloy, S., Cronan, J. E., Jr \& Freifelder, D. (1994). Microbial Genetics, 2nd edn, p. 311. Boston, MA : Jones and Bartlett. 
Maynard Smith, J. (1994). Estimating the minimum rate of genetic transformation in bacteria. J Evol Biol 7, 525-534.

Maynard Smith, J., Smith, N. H., O'Rourke, M. \& Spratt, B. G. (1993). How clonal are bacteria? Proc Natl Acad Sci USA 90, $4384-4388$.

Mevarech, M. \& Werczberger, R. (1985). Genetic transfer in Halobacterium volcanii. J Bacteriol 162, 461-462.

Mullakhanbhai, M. \& Larsen, H. (1975). Halobacterium volcanii, sp. nov, a Dead Sea Halobacterium with a moderate salt requirement. Biochim Biophys Acta 65, 506-508.

Poplawski, A. \& Bernander, R. (1997). Nucleoid structure and distribution in thermophilic archaea. J Bacteriol 179, 7625-7630.

Rosenshine, I. \& Mevarech, M. (1991). The kinetic of the genetic exchange process in Halobacterium volcanii mating. In General and Applied Aspects of Halophilic Micro-organisms, pp. 265-270. Edited by F. Rodriguez-Valera. New York: Plenum.

Rosenshein, I., Tchelet, R. \& Mevarech, M. (1989). The mechanism of DNA transfer in the mating system of an archaebacterium. Science 245, 1387-1389.

Schleper, C., Holz, I., Janekovic, D., Murphy, J. \& Zillig, W. (1995a). A multicopy plasmid of the thermophilic archaeon Sulfolobus effects its transfer to recipients by mating. J Bacteriol 177, $4417-4426$.
Schleper, C., Pühler, G., Holz, I., Gambacorta, A., Janekovic, D., Santarius, U., Klenk, H.-P. \& Zillig, W. (1995b). Picrophilus gen. nov., fam. nov: a novel heterotrophic, thermoacidophilic genus and family comprising archaea capable of growth around $\mathrm{pH} 0$. J Bacteriol 177, 7050-7059.

Stetter, K. O., Fiala, G., Huber, R. \& Segerer, A. (1990). Hyperthermophilic microorganisms. FEMS Microbiol Rev 75, 117-124.

Wilkins, B. M (1995). Gene transfer by bacterial conjugation: diversity of systems and functional specializations. In Population Genetics of Bacteria, p. 72. Edited by S. Baumberg, J. P. W. Young, E. M. H. Wellington \& J. R. Saunders. Cambridge: Cambridge University Press.

Willets, N. \& Skurray, R. (1980). The conjugation system of F-like plasmids. Annu Rev Genet 14, 41-76.

Woese, C. R., Kandler, O. \& Wheelis, M. (1990). Towards a natural system of organisms: proposal for the domains Archaea, Bacteria, and Eucarya. Proc Natl Acad Sci USA 87, 4576-4579.

Wood, E., Ghané, F. \& Grogan, D. (1997). Genetic responses of the thermophilic archaeon Sulfolobus acidocaldarius to short-wavelength UV light. J Bacteriol 179, 5693-5698.

Received 10 October 1997; revised 4 February 1998; accepted 9 February 1998. 